\title{
PRIORITAS STRATEGI PENINGKATAN KOMPETENSI PETANI PADI SAWAH DI KECAMATAN GUNUNG TOAR KABUPATEN KUANTAN SINGINGI PROVINSI RIAU
}

\section{Strategy Priority to Improve Competence of Rice Farmers in Gunung Toar District, Kuantan Singingi Regency, Riau Province}

\author{
Sri Ayu Kurniati dan Sisca Vaulina \\ Fakultas Pertanian Universitas Islam Riau. \\ J1. Kaharuddin Nasution No. 113, Pekanbaru 28284 Riau \\ Email: sriayukurniati@agr.uir.ac.id \\ [Diterima: November 2019; Disetujui: Desember 2019]
}

\begin{abstract}
The competence of farmers in cultivating comprises the accuracy of using production inputs, appropriate cultivation techniques, marketing of production, good administrative, and ability of using information technology. This study aims to analyze internal and external factors affecting farmers' competence and formulate strategic priorities in improving the competence of rice farmers. The research used a survey method located in Gunung Toar District, Kuantan Singingi Regency of Riau Province withnumber of sample of 50 rice farmers. The data source came from primary data and secondary data. Data were analyzed using SWOT and QSPM analysis. The results showed that the internal factors owned by farmers were the ability to use efficient marketing channels (strengths) and the use of communication tools that were still limited (weaknesses). While the external factors were the existence of government policies on food security (opportunities) and fluctuating production selling prices (threats). Through the IFE and EFE matrices, strategic positions are obtained in the ST strategy quadrant. QSPM assessment on the strategy of building cooperation with marketers as a permanent consumer is an alternative priority strategy to improve farmers' competence.
\end{abstract}

Keywords: Priority, Strategy, Paddy Field, SWOT, QSPM

\begin{abstract}
ABSTRAK
Kompetensi petani dalam berusahani padi sawah meliputi ketepatan penggunaan sarana produksi, teknik budidaya yang sesuai rekomendasi, pemasaran hasil produksi, ketertiban administrasi, dan penguasaan teknologi informasi. Penelitian ini bertujuan untuk menganalisis faktor internal dan eksternal yang mempengaruhi kompetensi petani dan merumuskan prioritas strategi dalam peningkatan kompetensi petani padi sawah. Penelitian menggunakan metode survei di Kecamatan Gunung Toar Kabupaten Kuantan Singingi Provinsi Riau dengan sampel sebanyak 50 petani. Sumber data berasal dari data primer dan data skunder. Analisis data secara desriptif kualitatif menggunakan analisis SWOT dan QSPM. Hasil penelitian menyatakan bahwa faktor internal yang dimiliki petani adalah kemampuan menggunakan saluran pemasaran yang efisien (kekuatan) dan penggunaan alat komunikasi yang masih terbatas (kelemahan). Sedangkan faktor eksternalnya yaitu adanya kebijakan pemerintah tentang ketahanan pangan (peluang) dan harga jual produksi yang berfluktuasi (ancaman). Melalui matriks IFE dan EFE diperoleh posisi strategi pada kuadran strategi ST. Penilaian QSPM pada strategi menjalin kerjasama dengan pemasar sebagai konsumen tetap adalah prioritas alternatif strategi peningkatan kompetensi petani.
\end{abstract}

Kata kunci: Prioritas, Strategi, Padi Sawah, SWOT, QSPM

\section{PENDAHULUAN}

Padi merupakan bahan pangan pokok yang bersifat multi fungsi. Produksi padi yang dihasilkan di setiap daerah diharapkan dapat berperan dalam menjaga ketahanan, kestabilan dan kemandirian pangan. Zakaria dan Nurasa
(2013) menyatakan bahwa kemandirian pangan merupakan alat ukur ketahanan pangan sehingga perlu adanya perhatian pada kedaulatan pangan. Komoditas padi memiliki tingkat sensitivitas yang tinggi pada aspek sosial, ekonomi dan politik terkait perannya 
sebagai bahan makanan utama penduduk Indonesia.

Sejalan dengan keberhasilan program tersebut maka peningkatan produksi dan produktivitas usahatani tidak terlepas dari peningkatan kemampuan petani dalam mengusahakan kegiatan produksi sesuai dengan kemampuan dan keahlian, khususnya dalam manajerial usahatani. Pengelolaan usahatani padi sawah di Kecamatan Gunung Toar Kabupaten Kuantan Singingi Provinsi Riau berkaitan erat dengan kompetensi petani untuk meningkatkan produksi. Penduduk Kecamatan Gunung Toar sebagian besar mengusahakan padi sawah meskipun produktivitas tiap-tiap desa berbeda tergantung kemampuan petani dalam mengelola usahataninya. Petani sebagai sumberdaya manusia merupakan input produksi yang keberadaannya sangat dominan terhadap produktivitas usahatani padi sawah.

Kompetensi adalah kemampuan melaksanakan suatu pekerjaan yang dilandasi oleh ketrampilan, pengetahuan dan sikap sesuai tuntutan pekerjaan tersebut (Wibowo, 2007). Kompetensi petani terbentuk dan secara tidak langsung tercermin dari karakteristik sosial dan ekonomi petani tersebut. Karakteristik sosial dan ekonomi meliputi umur, tingkat pendidikan formal, pengalaman berusahatani padi sawah, jumlah tanggungan keluarga, luas lahan padi sawah, penggunaan tenaga kerja dan jumlah modal yang secara umum masih belum optimal dan belum efisien. Kemampuan petani meningkatkan kompetensi haruslah diiringi oleh kesadaran untuk disiplin, mempunyai motivasi tinggi, berpikir kreatif dan inovatif sehingga menumbuhkan semangat dalam pengembangan usahatani padi sawah yang berkelanjutan.

Tinggi rendahnya kemampuan petani dalam meningkatkan kompetensi dipengaruhi oleh faktor lingkungan, baik secara internal maupun eksternal. Hambatan lingkungan internal diantaranya kelemahan petani dalam penerapan teknologi, minimnya penguasaaan input produksi, keterbatasan kepemilikan lahan, dan lemahnya akses permodalan. Sedangkan lingkungan eksternal yang mempengaruhi antara lain ketidakpastian iklim dan cuaca menyebabkan munculmya serangan hama dan organisme pengganggu tanaman serta ketidakstabilan harga produksi. Sementara kompetensi yang harus dimiliki petani dalam berusahani padi sawah adalah ketepatan penggunaan sarana produksi, teknik budidaya yang sesuai rekomendasi, pemasaran hasil produksi, ketertiban administrasi, dan penguasaan teknologi informasi.

Tugas penting petani sekaligus manajer usahatani adalah ketrampilan dalam merumuskan strategi yang menyangkut perluasan, pengembangan, pertumbuhan dan kelangsungan usaha, peningkatan daya saing dan pembangunan sosial ekonomi secara umum (Defidelwina, dkk, 2017). Tujuan penelitian ini adalah menganalisis faktor internal dan eksternal yang mempengaruhi kompetensi petani dan merumuskan prioritas strategi dalam peningkatan kompetensi petani padi sawah. Manfaat yang ingin dicapai adalah pemahaman terhadap pentingnya peningkatan kompetensi petani dalam rangka mewujudkan peningkatan produktivitas usahatani padi sawah di Kecamatan Gunung Toar Kabupaten Kuantan Singingi Provinsi Riau.

\section{METODE PENELITIAN}

Penelitian dilakukan di Kecamatan Gunung Toar Kabupaten Kuantan Singingi Provinsi Riau menggunakan metode survei dengan pertimbangan bahwa Kecamatan Gunung Toar memiliki tingkat produktivitas padi sawah tertinggi di Kabupaten Kuantan Singingi. Populasi penelitian mencakup keseluruhan petani padi sawah di Kecamatan Gunung Toar sedangkan pemilihan lokasi dan sampel penelitian dilakukan secara acak sederhana pada 5 desa, yaitu Desa Petapahan, Desa Koto Gunung, Desa Teberau Panjang, Desa Pisang Berebus, dan Desa Toar. Pada masing-masing desa diambil 10 petani sehingga total sampel sebanyak 50 petani. Sumber data penelitian berasal dari data primer dan data skunder.

\section{Analisis Data}

Pengolahan data menggunakan analisis deskriptif kualitatif yaitu menggambarkan kondisi daerah penelitian. Data yang diperoleh kemudian dikelompokkan, ditabulasi, dianalisis dan diinterpretasi berdasarkan tujuan penelitian.

Analisis lingkungan internal dan eksternal meliputi kekuatan, kelemahan, peluang dan ancaman menggunakan analisis SWOT. Hal ini bertujuan untuk mengidentifikasi faktor-faktor yang dapat meningkatkan kompetensi petani sehingga 
meningkatkan produksi dan produktivitas usahatani padi sawah. Secara umum implementasi analisis SWOT adalah:

1) Mengevaluasi indikator internal (kekuatan dan kelemahan) dan indikator eksternal (peluang dan ancaman)

2) Menyusun matriks IFE (Internal Factor Evaluation) dan matriks EFE (External Factor Evaluation)

Tabel 1. Matriks SWOT
3) Merumuskan strategi matriks SWOT dalam alternatif SO (StrenghtOpportunities), ST (Strenght-Threat), WO (Weaknessess-Opportunities), dan WT (Weaknessess-Threat)

\begin{tabular}{ccc}
\hline Faktor Internal & Kekuatan $(\mathrm{S})$ & Kelemahan $(\mathrm{W})$ \\
\hline Peluang $(\mathrm{O})$ & $\begin{array}{c}\text { Strategi SO } \\
\text { Dirumuskan dengan tujuan } \\
\text { memaksimalkan kekuatan untuk } \\
\text { memanfaatkan peluang }\end{array}$ & $\begin{array}{c}\text { Strategi WO } \\
\text { Dirumuskan dengan tujuan } \\
\text { meminimalkan kelemahan untuk } \\
\text { memanfaatkan peluang }\end{array}$ \\
\hline Ancaman $(\mathrm{T})$ & $\begin{array}{c}\text { Strategi ST } \\
\text { Dirumuskan dengan tujuan } \\
\text { memaksimalkan kekuatan untuk } \\
\text { mengatasi ancaman }\end{array}$ & $\begin{array}{c}\text { Strategi WT } \\
\text { Dirumuskan dengan tujuan } \\
\text { meminimalkan kelemahan dan } \\
\text { mengatasi ancaman }\end{array}$ \\
\hline
\end{tabular}

Sumber: Rangkuti (2002)

Quantitative Strategic Planning Matrix (QSPM) penerapannya dilakukan untuk menentukan faktor-faktor kunci dari suatu strategi melalui analisis SWOT, dimana masing-masing strategi diberi bobot dan disajikan dalam matriks. Hasil pembobotan faktor-faktor kunci yang telah teridentifikasi dikalikan dengan penilaian panel ahli kemudian diurutkan. Nilai tertinggi bobot akhir inilah yang diajadikan priotitas pilihan strategi (Yusuf dan Muhartono, 2017). Keuntungan menggunakan matriks QSPM adalah strategistrategi dapat diperiksa secara berurutan dan bersamaan dan tidak ada batasan untuk strategi yang dianalisis bersamaan (Setyorini, dkk, 2016).

\section{HASIL PEMBAHASAN}

\section{Analisis Faktor Internal dan Eksternal Peningkatan Kompetensi Petani}

Kompetensi yang diharapkan bagi petani padi sawah di Kecamatan Gunung Toar Kabupaten Kuantan Singingi Provinsi Riau adalah kemampuan dalam ketepatan penggunaan sarana produksi, teknik budidaya yang sesuai rekomendasi, pemasaran hasil produksi, ketertiban administrasi, dan penguasaan teknologi informasi. Matriks IFE dapat dilihat pada Tabel 2.
Berdasarkan Tabel 2 terlihat bahwa jumlah bobot indikator kekuatan sebesar 0,518 lebih besar daripada indikator kelemahan yaitu 0,482 . Indikator kekuatan yang memiliki bobot terbesar adalah kemampuan petani menggunakan saluran pemasaran yang efisien. Hal ini mengindikasikan bahwa petani meyakini jika pemasaran merupakan elemen penting bagi perkembangan hasil produksi padi sawah.

Biasanya setelah panen, petani melakukan penggilingan padi terlebih dahulu menggunakan mesin penggiling padi yang ada di desa untuk dipakai bersama-sama. Setelah berbentuk beras petani kemudian menjual melalui pedagang pengumpul dengan sistem pembayaran langsung. Tidak semua hasil produksi dijual ke padagang namun hanya sepertiga bagian saja, sedangkan dua pertiga bagian digunakan untuk konsumsi rumah tangga.

Indikator kelemahan yang memiliki bobot tertinggi adalah penggunaan alat komunikasi yang masih terbatas. Jenis alat komunikasi yang umum digunakan adalah telepon seluler (handphone/hp). Petani lebih banyak menggunakan hp untuk keperluan non usahatani, seperti mengetahui informasi keluarga di luar daerah. Kepemilikan alat komunikasi harusnya digunakan untuk mengetahui informasi harga terbaru, teknik budidaya yang lebih canggih dan ramah 
lingkungan, media komunikasi petani dan penyuluh sehingga petani menjadi lebih terampil dan menigkat kompetensi informasinya.

Tabel 2. Matriks IFE (Internal Factor Evaluation)

\begin{tabular}{llcc}
\hline \multicolumn{1}{c}{ Faktor Strategis Internal } & Bobot & Rating & $\begin{array}{c}\text { Nilai } \\
\text { Tertimbang }\end{array}$ \\
\hline Kekuatan (Strenght) & & 0,101 & 0,330 \\
1. Mampu menggunakan sarana produksi dengan baik & 0,108 & 3,27 & 0,381 \\
2. Melakukan teknik budidaya sesuai rekomendasi pihak terkait & 0,113 & 3,68 & 0,417 \\
3. Menggunakan saluran pemasaran dengan efisien & 0,103 & 3,32 & 0,341 \\
4. Manajemen usahatani cukup baik & 0,093 & 3,03 & 0,283 \\
5. Memahami penggunaan bibit unggul & 0,518 & - & $\mathbf{1 , 7 5 2}$ \\
\hline Subtotal & & & 0,268 \\
\hline Kelemahan (Weaknesses) & 0,091 & 2,95 & 0,404 \\
\hline 1. Belum melakukan administrasi pencatatan dengan baik & 0,112 & 3,64 & 0,268 \\
2. Penggunaann alat komunikasi masih terbatas & 0,091 & 2,95 & 0,335 \\
3. Kurang terampil menggunakan sistem informasi & 0,102 & 3,30 & 0,244 \\
4. Penerapan teknologi usahatani masih sederhana & 0,086 & 2,81 & $\mathbf{1 , 5 1 9}$ \\
5. Bereaksi pasif terhadap fluktuasi harga produksi & 0,482 & - & $\mathbf{3 , 2 7 1}$ \\
\hline Subtotal & $\mathbf{1 , 0 0 0}$ & & \\
\hline Total & &
\end{tabular}

Tabel 3. Matriks EFE (External Factor Evaluation)

\begin{tabular}{lccc}
\hline \multicolumn{1}{c}{ Faktor Strategis Eksternal } & Bobot & Rating & $\begin{array}{c}\text { Nilai } \\
\text { Tertimbang }\end{array}$ \\
\hline Peluang (Opportunities) & & & 0,475 \\
\hline 1. Adanya kebijakan pemerintah tentang ketahanan pangan & 0,124 & 3,84 & 0,404 \\
2. Peningkatan jumlah penduduk & 0,114 & 3,54 & 0,312 \\
3. Adanya permintaan pasar yang potensial & 0,100 & 3,11 & 0,296 \\
4. Berkembangnya produk pangan berbahan baku beras & 0,098 & 3,03 & 0,054 \\
5. Berkembangnya lembaga keuangan di pedesaan & 0,042 & 1,30 & $\mathbf{1 , 5 4 1}$ \\
\hline Subtotal & 0,478 & - & 0,404 \\
\hline Ancaman (Threat) & & 0,417 \\
\hline 1. Ketidakpastian perubahan iklim dan cuaca & 0,114 & 3,54 & 0,182 \\
2. Harga jual produksi berfluktuasi & 0,116 & 3,59 & 0,374 \\
3. Peningkatan harga input produksi & 0,077 & 2,38 & 0,345 \\
4. Persaingan harga produksi dengan daerah lain & 0,110 & 3,41 & $\mathbf{1 , 7 2 2}$ \\
5. Munculnya hama dan penyakit & 0,105 & 3,27 & $\mathbf{3 , 2 6 3}$ \\
\hline Subtotal & 0,522 & - & \\
\hline Total & $\mathbf{1 , 0 0 0}$ & & \\
\hline
\end{tabular}

Pada Tabel 3 terlihat bahwa indikator ancaman memiliki jumlah bobot 0,522 lebih besar dibandingkan bobot peluang eksternal yaitu 0,478. Kondisi ini mengindikasikan bahwa perlu adanya perhatian dari petani untuk meminimalkan ancaman yang ada dengan mampu memanfaatkan sejumlah peluang. Indikator ancaman yang mempunyai skor bobot terbesar adalah harga jual produksi yang berfluktuasi.

Pemasaran produk pangan umumnya termasuk pada struktur pasar persaingan sempurna sehingga penetapan harga berdasarkan kebijakan harga pasar, dimana petani sebagai penerima harga (price taker).
Hal ini menyebabkan petani harus menerima harga yang berlaku. Fluktuasi harga produksi padi sawah biasanya disebabkan oleh jumlah produksi yang berkurang akibat gagal panen, iklim yang tidak menentu, kenaikan harga bibit, pupuk, sehingga mempengaruhi kualitas beras yang dihasilkan.

Adanya kebijakan pemerintah tentang ketahanan pangan merupakan indikator peluang yang memberikan bobot tertinggi. Kebijakan ini merupakan regulasi pemerintah untuk melindungi petani sebagai produsen dan masyarakat sebagai konsumen dari sisi permintaan dan penawaran. Ketersediaan pangan yang berasal dari internal wilayah menjadi nilai positif bagi katahanan pangan 
wilayah tersebut dan mengurangi ketergantungan dari wilayah/negara lain. Kecamatan Gunung Toar meskipun bukan basis komoditas padi sawah di Provinsi Riau namun dapat diandalkan dalam penyediaan beras di Kabupaten Kuantan Singingi.

Berdasarkan matriks IFE diketahui bahwa selisih antara skor kekuatan dan kelemahan sebesar 0,233 (dari sisi kekuatan) sedangkan matriks EFE memperlihatkan selisih antara peluang dan ancaman sebesar 0,181 (dari sisi ancaman). Hal ini menyatakan bahwa posisi strategi berada pada kuadran 2 dengan strategi yang dapat ditempuh yaitu ST dengan menggunakan kekuatan internal utama untuk meminimalkan atau menghindari ancaman eksternal. Untuk lebih jelas dapat dilihat pada Gambar 1 berikut:

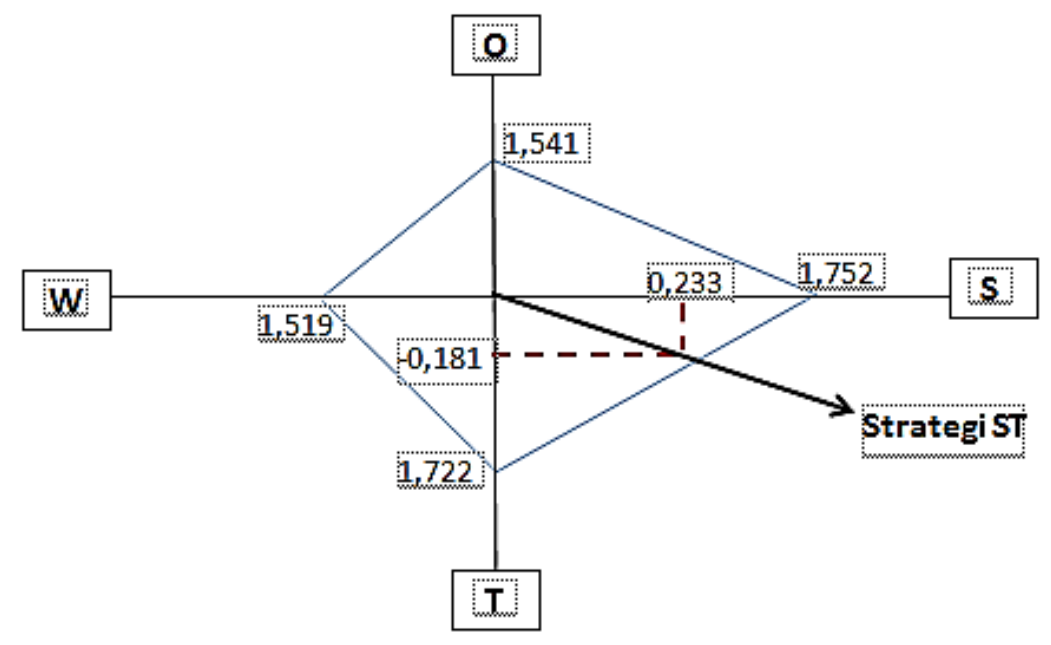

Gambar 1. Diagram Analisis SWOT

Tabel 4. Matriks SWOT

\begin{tabular}{|c|c|c|}
\hline Faktor Internal & $\begin{array}{l}\text { Kekuatan (Strenght) } \\
\text { 1. Mampu menggunakan sarana } \\
\text { produksi dengan baik } \\
\text { 2. Melakukan teknik budidaya } \\
\text { sesuai rekomendasi pihak } \\
\text { terkait } \\
\text { 3. Menggunakan saluran } \\
\text { pemasaran dengan efisien } \\
\text { 4. Manajemen usahatani cukup } \\
\text { baik } \\
\text { 5. Memahami penggunaan bibit } \\
\text { unggul }\end{array}$ & $\begin{array}{l}\text { Kelemahan (Weaknessess) } \\
\text { 1. Belum melakukan administrasi } \\
\text { pencatatan dengan baik } \\
\text { 2. Penggunaann alat komunikasi } \\
\text { masih terbatas } \\
\text { 3. Kurang terampil menggunakan } \\
\text { sistem informasi } \\
\text { 4. Penerapan teknologi usahatani } \\
\text { masih sederhana } \\
\text { 5. Bereaksi pasif terhadap } \\
\text { fluktuasi harga produksi }\end{array}$ \\
\hline $\begin{array}{l}\text { Peluang (Opportunities) } \\
\text { 1. Adanya kebijakan pemerintah } \\
\text { tentang ketahanan pangan } \\
\text { 2. Peningkatan jumlah penduduk } \\
\text { 3. Adanya permintaan pasar yang } \\
\text { potensial } \\
\text { 4. Berkembangnya produk pangan } \\
\text { berbahan baku beras } \\
\text { 5. Berkembangnya lembaga } \\
\text { keuangan di pedesaan }\end{array}$ & $\underline{\text { Strategi SO }}$ & Strategi WO \\
\hline $\begin{array}{l}\quad \text { Ancaman (Threat) } \\
\text { 1. Ketidakpastian perubahan iklim } \\
\text { dan cuaca } \\
\text { 2. Harga jual produksi berfluktuasi } \\
\text { 3. Peningkatan harga input produksi } \\
\text { 4. Persaingan harga produksi }\end{array}$ & \begin{tabular}{l}
\multicolumn{1}{c}{ Strategi ST } \\
1. Menggunakan varian bibit yang \\
memiliki daya tahan terhadap \\
perubahan iklim dan serangan \\
hama (S2, S5, T1, T5)
\end{tabular} & $\underline{\text { Strategi WT }}$ \\
\hline
\end{tabular}




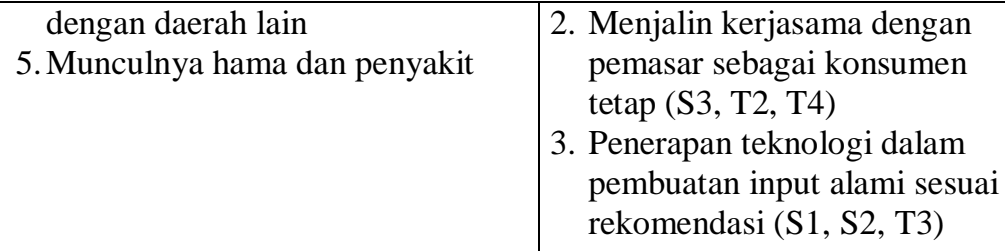

\section{Prioritas Strategi Peningkatan Kompetensi Petani}

Berdasarkan matriks SWOT maka terdapat 3 strategi yang dapat dilaksanakan dalam meningkatkan kompetensi petani mengusahakan usahatani padi sawah di Kecamatan Gunung Toar Kabupaten Kuantan Singingi, yaitu menggunakan varian bibit yang

Tabel 5. Rekapitulasi Penilaian QSPM

\begin{tabular}{clcc}
\hline & \multicolumn{1}{c}{ Alternatif Strategi } & TAS & Prioritas \\
\hline ST 1 & $\begin{array}{l}\text { Menggunakan varian bibit yang memiliki daya tahan terhadap perubahan } \\
\text { iklim dan serangan hama }\end{array}$ & 6,78 & III \\
ST 2 & Menjalin kerjasama dengan pemasar sebagai konsumen tetap & 8,83 & I \\
ST 3 & penerapan teknologi dalam pembuatan input alami sesuai rekomendasi & 7,21 & II
\end{tabular}

Tabel 5 memperlihatkan bahwa menjalin kerjasama dengan mitra yang memasarkan hasil produksi padi sawah petani dan menjadikan mitra tersebut sebagai konsumen tetap merupakan prioritas strategi utama yang dapat meningkatkan kompetensi petani. Kompetensi yang harus dimiliki untuk mewujudkan prioritas strategi tersebut antara lain manajemen pemasaran, manajemen administrasi, dan penguasaan teknologi informasi.

Prioritas strategi kedua yang dapat ditempuh petani adalah menggunakan teknologi tepat guna dalam mengusahakan input produksi secara alami sesuai standar yang direkomendasi oleh lembaga terkait. Pembuatan input meliputi pupuk alami dan pestisida alami, penggunaan tenaga kerja dari dalam keluarga namun sangat berkompeten dalam berusahatani padi sawah. Prioritas strategi ketiga dapat bersinergi dengan prioritas strategi kedua yaitu dalam adopsi teknologi dan inovasi.

\section{KESIMPULAN}

1. Faktor internal yang dimiliki petani adalah kemampuan menggunakan saluran pemasaran yang efisien (kekuatan) dan penggunaan alat komunikasi yang masih terbatas (kelemahan). Sedangkan faktor memiliki daya tahan terhadap perubahan iklim dan serangan hama, menjalin kerjasama dengan pemasar sebagai konsumen tetap, dan penerapan teknologi dalam pembuatan input alami sesuai rekomendasi. Selanjutnya melalui analisis QSPM dapat ditentukan prioritas strategi, terlihat pada Tabel 5: eksternalnya yaitu adanya kebijakan pemerintah tentang ketahanan pangan (peluang) dan harga jual produksi yang berfluktuasi (ancaman). Melalui matriks IFE dan EFE diperoleh posisi strategi pada kuadran 2 dengan strategi ST

2. Penilaian QSPM pada strategi menjalin kerjasama dengan pemasar sebagai konsumen tetap adalah prioritas alternatif strategi peningkatan kompetensi petani.

\section{DAFTAR PUSTAKA}

Defidelwina, A. Ariyanto dan Y. A'ini. 2017. Strategi Peningkatan Produksi dan Produktivitas Padi Sawah di Kabupaten Rokan Hulu. Dalam Prosiding Seminar Nasional Pengembangan Sumberdaya Pedesaaan dan Kearifan Lokal Berkelanjutan, Purwokerto, 17-18 November 2017.

Rangkuti, F. 2002. Analisis SWOT: Teknik Membedah Kasus Bisnis, Reorientasi Konsep Perencanaan Strategis untuk Menghadapi Abad 21. Gramedia Pustaka Utama, Jakarta.

Setyorini. H, M. Effendi, dan I. Santoso. 2016. Analisis Strategi Pemasaran Menggunakan Matriks SWOT dan QSPM (Studi Kasus: Restoran WS Soekarno Hatta Malang). Jurnal 
Prioritas Strategi Peningkatan Kompetensi Petani Padi Sawah di Kecamatan Gunung Toar Kabupaten Kuantan Singingi Provinsi Riau

Teknologi dan Manajemen Agroindustri, 5(1): 46-53.

Yusuf. R dan R. Muhartono. 2017. Strategi Pengembangan Usaha Perikanan Tangkap di Kabupaten Kayong Utara. Jurnal Kebijakan Sosek KP, 7(2): 103114.

Widodo, A. 2007. Pendidikan IPA di SD. UPI Press, Bandung

Zakaria A. K dan T. Nurasa. 2013. Strategi Penggalangan Petani untuk Mendukung Program Peningkatan Produksi Padi Berkelanjutan. Jurnal Analisis Kebijakan Pertanian, 11(2): 75-87. 
